\title{
Dual Language: A Combined Dual Language Framework for Implementation: A 90/10 and 50/50 Model Design
}

\author{
Roslyn J. F. Billy ${ }^{1} \&$ Carmen Medina Garríguez ${ }^{2}$ \\ ${ }^{1}$ Prince George's County Public Schools, Upper Marlboro, Maryland, USA \\ ${ }^{2}$ Escuela Oficial de Idiomas de Antequera, Antequera (Málaga), Spain \\ Correspondence: Carmen Medina Garríguez, Escuela Oficial de Idiomas de Antequera, Antequera (Málaga), \\ Spain.
}

Received: June 4, 2019 Accepted: September 24, 2019 Online Published: September 27, 2019

doi: 10.5539/elt.v12n10p108 URL: https://doi.org/10.5539/elt.v12n10p108

\begin{abstract}
Dual Language programs are starting to resurface amongst the best practices for increasing literacy and academic language acquisition. Substantial evidence exists to support dual language (DL) education as a viable and enriching method of supporting high levels of academic achievement for both English Language Learners (ELLs) and English-speaking students (as cited in Ray, 2009). With that being said, there is no doubt that a DL program will increase the academic achievement of Culturally Linguistically Diverse (CDL) students. However, the question that arises in the implementation of DL programs is, which model either the $90 / 10$ or the $50 / 50$ is effective in sustaining academic achievement of CLD students during their educational experience? One issue that can impact Dual Language Education (DLE) program design concerns the allocation of time given to each language (Lindholm-Leary, 2012). The purpose of this research is to test the implementation of the conceptual dual language framework developed by the researchers that embraces both the 90/10 and 50/50 model allowing for a blended allocation of time given to each language for biliteracy mastery. Although the focus of the study took place in the United States, the researchers have also reviewed Europe and the Middle East where the Content and Language Integrated Learning (CLIL) model is very popular as other possible contexts for implementation of the framework.
\end{abstract}

Keywords: dual language education, ell, cultural and linguistic diversity, bilingual education, CLIL

\section{Introduction}

When we consider the term bilingual, we think of being able to use two languages. Baker and Wright (2017) compared the term bilingual to bicycle (two wheels) or binoculars (two eyes) to express the apparent simplicity of the term when in fact its outreach was far more complicated. They go on to state that there are a number of issues to consider, for instance, bilingual fluency or usage in the languages, bilingualism as an individual or as part of a broader group or geographical area. Bilingual Education has existed for centuries and it is difficult to pinpoint a definition that can satisfy the numerous combinations of languages, nationalities, grammar rules, political and cultural settings, and innumerable variables that make bilingualism such a complex and elusive field (Titone, 1993; Deshays, 2003; Bialystok, 2006).

In this paper, we will also review three different scenarios: the USA, Europe and the Middle East, and propose a combined model which could be applicable to any language in any context.

\subsection{Dual Language}

Dual Language and Bilingual Education consist of both language-majority and language-minority students and both languages are taught, usually for an equal amount of time (Varghese \& Park, 2010). The two models of instruction consistent with dual language instruction are the 90/10 and 50/50 model. In recent years, there has been an attack on bilingual education in the United States. Dual language education has surfaced as a prominent alternative for those groups who wish to use immigrant students' heritage language in schooling (Varghese \& Park, 2010), which brings attention to the models of instruction of dual language, and which model is proven to be the most effective for instruction of Culturally Linguistically Diverse students. Both the 90/10 and 50/50 models have shown success in grade levels K-5; however, the success of dual language programs from grades 6-12 has been limited due to the lack of research. Most of the research on Dual Language Education programs 
has been conducted to document the outcomes of students in DLE programs (Lindholm-Leary, 2012). Thus, leading us to conclude that there is a need for more research in the area of dual language and secondary education.

\subsection{0/10 Model}

As mentioned above, there are two models generally associated with Dual Language Education: the 90/10 and $50 / 50$. The $90 / 10$ model where $90 \%$ of the daily instruction is devoted to content in the target language, while $10 \%$ of the instructional day is in English. All content instruction occurs in the partner language, and English time is used to develop oral language proficiency and some preliteracy (Lindholm-Leary, 2012).

\section{$1.350 / 50$ Model}

In the 50/50 dual language education model, $50 \%$ of the daily instruction is devoted to content in the target language, while the other $50 \%$ of the instructional day is in English. Even though the instruction of the target language is broken into equal amounts of time of exposure; mastery of the target language does not always happen. Although the great majority of the research focuses on academic achievement, there is some limited research on oral language development and other student outcomes (Lindholm-Leary, 2012).

\section{$1.490 / 10$ and 50/50 Model}

The researchers have developed a model that combines both the 90/10 and 50/50 dual language education frameworks. The theories that embed the model are the following: Cognitive Academic Language Proficiency, Universal Grammar, Erikson's 8 Stages of Development, and Stephen Krashen's theory of Second Language Acquisition. Cognitive Academic Language Proficiency (Cummins, 2008) is characterized by being abstract, context reduced, and specialized. In addition to acquiring the language, learners need to develop skills such as comparing, classifying, synthesizing, evaluating, and inferring when developing academic competence. Research from Collier and Thomas (2004) has shown that it may take children with no prior instruction or no support in native language development at least seven years to develop CALP. Universal Grammar (Chomsky, 1965) also known as the Language Acquisition Device states that humans are born with the instinct or "innate facility" for acquiring language. Erikson's 8 Stages of Development (Erikson, 1958) maintains that humans evolve through eight stages of psychosocial development from infancy to adulthood. These eight stages include trust vs mistrust, autonomy vs shame/doubt, initiative vs guilt, industry vs inferiority, identity vs role confusion, intimacy vs isolation, generativity vs stagnation, and integrity vs despair.

Stephen Krashen's (Krashen 1981a) theory of second language acquisition is the product of a subconscious process very similar to the process children undergo when they acquire their first language. This process entails meaningful interaction in the target language or natural communication because the speakers are concentrated not on the form of their utterances, but on the act of communication.

In Appendix A, Table 1 shows the combined dual language framework as it would be implemented through the various grade levels and the rationale supporting the time frame of implementation.

\section{Implementation of 90/10 and 50/50 Framework}

The framework mentioned in Table 1(Appendix) refers to using both the 90/10 and 50/50 model at certain grade levels over the course of K-12 instruction. The framework was developed through a period of observations of Bilingual and Dual Language programs across the United States, Europe, and the Middle East. The intention of the framework is to increase mastery of the target language through the use of both dual language models.

The framework begins with the use of the 90/10 model in grade levels K-2. The rationale to support the use of the 90/10 model in grade levels K-2 is as follows: (1) LAD (Language Acquisition Device) as its at peak functioning level in grades K-2, (2) Hours of exposure to the target language, and (3) Language Rich Instructional Environment. The LAD (Language Acquisition Device), Stephen Krashen describes the LAD as the part of the brain which allows individuals to acquire language through the method of comprehensible input. While Noam Chomsky referred to the LAD as Universal Grammar. Both theorists agree that an individual can acquire a target language at a rapid pace until age seven, when the LAD/Universal Grammar part of the brain tend to slow acquisition as age progresses. Hours of exposure in lieu of the LAD/Universal Grammar is critical within the grade levels of K-2. The more exposure to the target language in reference to the use of the 90/10 model will provide the maximum amount of time to ensure acquisition. The last consideration in the development of the combined dual language framework is language-rich instructional environment. A language enriched environment during the primary years of education is recommended in order to promote high levels of literacy. In language-rich classrooms the children often become authors themselves, with their stories, autobiographies, essays, and reports being read to other children and published, with laminated covers perhaps, 
for the library (Thaiss, 1986, p. 4).

The 50/50 model is implemented from grades 3-9 to allow for students to adapt to code switching and mastery use of the target language. The rationale of maintaining the 50/50 model at grades 3-9 allows participants to master CALP (Cognitive Academic Language Proficiency) within both target languages of instruction. Grades 10 and 11 would use 90/10 model at the 10th grade level and 100\% immersion at grade 11 . At this point the participants' instructional experience will include that of CALP in both target languages, which allow participants to flourish in a full immersion environment. Participants in 12th grade would have the opportunity to experience full immersion the first half of the school year and 50/50 the second half of the school year. The rationale is that 12 th grade participants to take part in full immersion and then 50/50 allows for full CALP and college and career readiness.

\section{Europe}

\subsection{Content and Language Integrated Learning}

Migration is one of the most relevant factors in the development of the European model of bilingual education. In some European countries, bilingual education in public schools is derived from the need to integrate foreigners or from the need to collaborate with neighbors (Cabello, 2017). A detailed evolution of the Council of Europe's Language Policy (2019) can be found under Milestones on its website. The aftermath of WWII solidified the idea of a peaceful co-existence, and the understanding of cultures and languages was established as a measure to ensure this. The idea of a unified language policy is already hinted at in the 1954 Paris Treaty No. 018 (COE, 2019, Summary): The purpose of this Convention is to develop mutual understanding among the peoples of Europe and reciprocal appreciation of their cultural diversity, to safeguard European culture, to promote national contributions to Europe's common cultural heritage respecting the same fundamental values and to encourage in particular the study of the languages, history and civilization of the Parties to the Convention.

In 1962, the Council for Cultural Co-operation adopted modern language teaching as a key objective. The Common European Framework of Reference for Languages: Learning, Teaching, Assessment (CEFR, 2001), and its updated CEFR Companion Volume with New Descriptors (2018) are just two of the varied products of the CE's ongoing initiatives.

Under the umbrella of the Council of Europe's successive agreements, each country's Ministry of Education has developed their "bilingual/multilingual/plurilingual" education plan. The most influential languages are available in the majority of European public education systems. The language policy appears in a wide variety of sociolinguistic contexts derived from a diverse educational history and is strongly supported by European institutions. The models vary from schools where all subjects are taught through two languages to more partial models where the target language is used to teach only one or two subjects. The Content and Language Integrated Learning (CLIL) model is considered a vital methodology in achieving the European Union (EU) policy aims of plurilingualism.

There are currently (May 2019), 24 official languages in the EU (Bulgarian, Croatian, Czech, Danish, Dutch, English, Estonian, Finnish, French, German, Greek, Hungarian, Irish, Italian, Latvian, Lithuanian, Maltese, Polish, Portuguese, Romanian, Slovak, Slovene, Spanish and Swedish), and over 60 minority languages which include Basque, Catalan, Frisian, Saami, Welsh and Yiddish (EUStats, 2018).

This linguistic diversity alone provides a challenge when it comes to a linguistic policy regarding bilingual, multilingual and plurilingual models. The EU strives to protect linguistic diversity while at the same time promoting language learning. It supports language learning because:

- better language skills improve job prospects;

- understanding diverse languages increases cultural awareness and understanding; and,

- a multilingual staff improves business and effective trade across Europe.

The different European language policy initiatives have catapulted the language industry (translation, interpretation, language teaching and teaching technologies) which is one of the fastest growing areas of the economy (EuroStat Statistics Explained, 2018). The European Language Portfolio (ELP) was another action developed by the Language Policy Programme to support the development of learner autonomy, plurilingualism and intercultural awareness and competence as well as to allow users to record their language learning achievements alongside their experience of learning and using languages (Council of Europe, 2019, May 23). The inclusion of "mediation" as a "new skill" in the CEFR Companion Volume (Council of Europe, 2019, May 
29) exemplifies the continuous efforts of the Language Policy Programme to support the importance of a linguistically diversified Europe.

During the past decades, the European members have aimed to improve the quality of the education and training systems of the member states, to facilitate access to education and training for all, and open education and training to the world. Some of the specific objectives include the improvement of teacher training and the learning of foreign languages, increased mobility and exchanges, and making learning more attractive (Cabello, 2017). Europe has also established procedures to assess the linguistic competence that is being achieved through its actions. The first of these was the European Survey of Linguistic Competencies which can be found in Survey Lang (2019).

The European Centre for Modern Languages (ECML) of the Council of Europe was created in 1994. It is currently one of Europe's most active institutions when it comes to researching, designing and developing the linguistic policies of the Union. It is self-defined as a "Center to promote quality language education in Europe" and its vision is "a Europe committed to linguistic and cultural diversity, where the key role of quality language education in achieving intercultural dialogue, democratic citizenship and social cohesion is recognized and supported" (ECML, 2019).

\subsection{Three Countries, Three Models}

\subsubsection{Germany}

In the German education system, the definition of the school curriculum depends on each Länder, although the uniformity of the educational structure is guaranteed by a 1964 agreement between the Länders. Bilingual education exists in over 400 institutes of Average Education in Germany, namely in English and French although Italian, Russian and Spanish have also been included. The characteristic feature is that subjects such as Geography, Social Sciences, Politics, History, Natural Sciences, Art, Physical Education, etc. are taught in a foreign language.

The Länd of Berlin bilingual model brings together students of different nationalities, from preschool to university access, in the same class. Students are already bilingual, or have a high knowledge of both languages, upon entering the program. In these classes, half of the students have German as their mother tongue and the other half as a different language. This also applies to the teachers. (Cabello, 2017).

In most cases, in the first two years of Primary school, children learn to read in their mother tongue and learn the foreign language only orally, although Mathematics is always taught in German. Music, Art, Physical Education and Ethics are also taught in the native language. From 1st to 4th year of Primary school, Natural Sciences are taught in the non-German language. By 3rd grade students should have learned to read and write in the foreign language. In 5th and 6th grade, Geography, Biology and History are taught in the non-German language to all students.

At most schools, half of the teachers are native Germans and the other half are from the corresponding foreign language. Each teacher instructs their corresponding subject in their mother tongue. Teachers must be qualified in the foreign language and in the subject they teach. The universities have programs that cater for the needs of teachers who are in search of an additional qualification to teach in a bilingual institution. (Cabello, 2017).

\subsubsection{Finland}

Finland is a multilingual state whose official language policy is embodied in constitutional law, which established Finnish and Swedish as the national languages of the new republic in 1917 (Marsh, 2012). In Finland, the Central Government establishes the study plans, but each region implements them. Thus, many competences are granted to the educational centers themselves. Since there are two national languages, children can choose between the Finnish and the Swedish track. Instruction in a foreign language or the second national language usually starts in the third grade of comprehensive school, although some students already take up a foreign language in the first or second grade.

More than 50 languages are taught through the scheme. In autumn 2012, about 14,000 pupils attended the foreign language or second language classes across the country. Some of the languages include Russian, Arabic, English, Estonian, Chinese and Spanish, as well as languages of significant immigrant communities including Somali, Kurdish, Albanian and Vietnamese (Weaver, 2015).

The Finnish Basic Education Act (Section 11), states that the basic education syllabus shall contain core subjects: Mother tongue and Literature, the second national language (Finnish or Swedish), Foreign Languages, Environmental Studies, Health Education, Religious Education or Ethics, History, Social Studies, Mathematics, 
Physics, Chemistry, Biology, Geography, Physical Education, Music, Art, Crafts, and Home Economics.

In the second stage of basic education (13 to 15), and in the centers offering Bilingual Teaching, Home Economics, Biology, Geography and History and Social Sciences are taught in a second language, ordered according to their demand. In Baccalaureate (16 to 19), the most frequently taught subjects are: History, Social Sciences, Geography, Biology, Chemistry and Psychology.

Finland also follows the CLIL methodology although the efficacy of the results has yet to be fully researched and established.

Nevertheless, Daily Finland (2018) published an article entitled 93\% of Finnish Residents Bilingual which included a paragraph stating, "Knowledge of languages grew from 1995 until 2012, when 93 per cent of the population aged 18 to 64 said they knew some foreign language at least a little. In 1995 and 2000, ten percentage points fewer men than women said they knew foreign languages. The difference had halved by 2017. In 2017, there were as many foreign language speakers as five years ago - 93 per cent of the population aged 18 to 64." The researchers found this interesting as several questions arose: Was there a model already in place back then and if so, how has it changed and why hasn't there been an increase in the percentage of the population that currently speak one or more foreign languages?

\subsubsection{Spain}

Education policies in Spain are centralized in the Ministry of Education. However, each autonomous region can adapt the central framework to its specific characteristics. This relative freedom of action has given way to notable differences amongst the bilingual education models which each region has chosen. It has also produced differences in the English skills that teachers require in order to participate in the bilingual programs. In Asturias, where more students study in English than in any other region $(52.3 \%$ in elementary school and $33.7 \%$ in high school), teachers only need to have an intermediate level (B2). The same is true in Andalusia, where $30.5 \%$ of elementary school students and 28.6\% of high school students study in English. However, in Madrid which has the lowest level of English teaching in schools, teachers are required to have an Advanced level of English (C1), (El País in English, 2018).

We are going to focus on the southern region of Spain, Andalusia, where 235 public teaching centers provide bilingual education in the province of Seville alone. More specifically, during the 2018 - 2019 academic year, five Primary schools, and five Secondary Education High Schools were incorporated to the previous list of bilingual Spanish-English schools.

The expansion of the network of bilingual centers is one of the proposals of the Strategic Plan for the Development of Languages in Andalusia Horizon 2020, which also includes the gradual extension of compulsory learning of two foreign languages up to Secondary Education, the improvement in training of teachers, and the advancement of the study of a foreign language to the second cycle of Pre-school (0-6), (Benitez, 2018).

The precursor to the current situation was the arrival of the Plurilingualism Plan in 2005. The implementation of the Strategic Plan for the Development of Languages in Andalusia Horizon 2020 was included as a specific measure in the Educational Success Plan. One of the former Andalusian Government's main objectives was to develop the linguistic competence of the students. It also aimed to improve the methodology applied by teachers, increase the number of teachers with ' $\mathrm{Cl}$ ' accreditation and increase the level acquired by students in at least one language other than the mother tongue, in order to comply with the European directive: " $50 \%$ of 15 -year-old students reach at least level 'B1' in a language other than their own" (Council of Europe, 2019).

The teaching of languages "has always been a priority in Andalusia", even more so since the implementation in 2005 of the Plan for the Promotion of Plurilingualism, which radically transformed the system of language learning in the last 15 years; thus, consolidating Andalusia as the community where most languages are taught (German, Arabic, Chinese, French, Modern Greek, English, Italian, Japanese, Portuguese, Russian and Spanish for foreigners).

The Official Schools of Languages were created in 1911. With the advent of the European Language policies, these publicly funded centers of education dedicated to the specialized teaching of modern languages became pivotal not only in offering the population aged 16 and above access to language learning at a very moderate fee, but also in the training of teachers in different languages. There are currently 51 schools in Andalusia alone and another approximately 173 distributed across Spain.

With regards to mainstream education, a policy handbook was published which expressly recommends the CLIL methodology in Early Childhood Education with the necessary adaptations to the age and the official curriculum. The handbook also recommends the CLIL methodology for Vocational Training and the Teaching of adults, as 
well as the specific training of teachers.

CLIL is a language teaching methodology in which the emphasis is on content rather than form (Marsh, 2012). Despite the popularity of the CLIL methodology, there has been some debate in recent years regarding the efficacy of the model. However, much research is still required across Europe to determine whether it is a successful model from both the teaching and the learning perspectives.

Getting back to the Spanish model, in the first years of learning foreign languages, listening and speaking are the key objective gradually evolving to the use of the five skills (listening, speaking, reading and writing.)

The usual distribution of hours in the foreign language according to levels in the second phase of Pre-school (3 to 6), is at least one and a half hours a week per course. At Primary School (6 to 12), it is compulsory to teach Natural Sciences and Social Science in the foreign language. Other subjects that can also be taught if previously authorized are: Education for Citizenship, Digital Culture and Practice, Physical Education and Artistic Education. At High School (12 to 16) the number of hours varies according to the model but is usually 2 to 3 hours a week. Optional subjects can also be taught in English if previously authorized by the Consejería de Educación (Educational authority in Andalusia). The total combination of foreign language and non-foreign language hours must make up 30\% of the students' schedules (9 hours). However, it is possible and desirable that schools increase the hours as they grow in subjects and qualified teachers. (Consejería de Educación y Ciencia de la Junta de Andalucía, 2017). As can be deduced, there is much ongoing debate in Spain regarding the efficacy of the "plurilingual" model regarding learner's linguistic abilities, teachers' qualification and cost-effectiveness which reinforces the idea that a combined dual language model may be an option to consider in this context.

\section{The Middle East: CLIL at a Technical College in the United Arab Emirates}

At the National Geographic Learning Conference held in Manama, Bahrain in November 2018, Dr. K.D. Harrison who delivered a lecture summarizing his work on lost or endangered languages was asked if Arabic was an endangered language. Much to the relief of the audience (mostly teachers in the Gulf Corporation Council -GCC- region), he said that Arabic had a healthy language future and that a major feature in the conservation of a language was the idea of ownership (Harrison, 2018).

We have started this section with this reference because it is a major concern that appears in the literature when reviewing bilingual education in the Middle East (Raddawi \& Meslem, 2015).

The reason English is the chosen language of instruction for bilingual education in the Middle East is slightly different to the European case. In the Middle East, two major factors have influenced the choice of English: a) Being under British influence, and b) The oil boom which brought about an influx of immigrants who used English as a lingua franca (Hopkyns, 2014).

Initially, this choice was practical and covered a purpose, but with the onset of nationalization, several Middle Eastern countries are beginning to witness a disinterest on behalf of Arabic speakers (Habbash \& Troudi, 2015) who claim that Arabic is being weakened mainly because of how it is perceived and feel English poses a threat. Nowadays, Arabic is considered less modern, so speakers are less emotionally attached, and thus, less willing to learn it. Arabic is looked upon in terms of identity, tradition, religion, culture and localism while English is identified to internationalism, modernity, economy and business (Gallagher, 2011).

Dubai in particular offers a kaleidoscope of international and national schools. Government schools offer the UAE National Curriculum. All subjects are taught in Arabic, with the exception of English (Azzam, 2015). Most of the international schools (American, British, French, German, Indian, to name a few) either offer the curriculum in English or have English as a priority subject. This veritable ragbag of K-12 education means that when students arrive to university the levels they bring can vary from -A1 to $\mathrm{C} 1+$, using the CEFR levels.

The hands-on experience to this situation has been the five years spent at two Middle Eastern universities, one in Saudi Arabia and one in the United Arab Emirates (UAE). Working closely with the colleagues from Arabic and Emirati studies, they claim that students find learning Arabic extremely difficult and thus postpone its study as long as possible. When students were asked why they found Arabic so difficult, most complained that it was because they had focused on their English while they were at High School. 90\% of the private school student population, study at international schools and travel abroad several times a year using English as a means of communication (Education UAE, 2018). This situation has raised alarm bells among the Ministries of Education who have decided to develop policies that bring back the interest in the language of the Quran.

For this paper, we have focused on the model being used in the UAE at a male higher education technical college. The college delivers its instruction for all programs in English. It is a multicultural institution with professionals 
from all over the globe with varying degrees of English language proficiency. Since there is a variety of programs and the instruction is in English, the chosen model is Content and Language Integrated Learning.

Students access the college by either direct entry or going through the Foundations program. This Foundation program has undergone a profound transformation in order to embrace and comply with the college's new 2.0 vision. The 2014-2015 academic year brought about a change from semesters to cycle-based instruction. Needless to say, that this initiative challenged curriculum developers, teachers and students alike. Curriculum developers had to condense content into a five-level academic curriculum ranging from Pre-Foundations (CEFR A1) to Level 4 (CEFR B1+). This drastic change took place in order to support students in reaching the current college's entry cutoff of the Emirates Standardized Test (EmSAT Achieve Test) 1100 (equivalent to IELTS band $5)$.

The Foundations Intensive Program ranges from 6 to 8 weeks. During that period, students receive instruction in English to prepare them for either progressing to the following level or passing the EmSAT and progressing to their Bachelor program. The program's main objective is to prepare students to pass said exam.

In an effort to aid students in this challenging trajectory, Foundations was further transformed. The Innovative Learning Centers were created to boost students' usage of the English language, not only in the academic environment, but also in everyday scenarios, thus encouraging field trips, critical thinking, problem solving, design thinking activities as well as developing typing, IT and study skills.

Also, under the umbrella of the General Academic Requirements Division (GARD), Foundations collaborates closely with the Academic Success Program (ASP) in order to support at risk students via emotional intelligence activities, differentiated learning and scaffolding, thus providing a solid background in ways of acquiring, processing and constructing content as well as making sense of ideas.

The GARD encompasses Arabic and Emirati Studies, the Academic Success Program, Foundations and General Studies. Part of its mission is to "enhance and integrate the academic and personal development and growth of HCT students through the development of a student-centered learning environment that will provide a comprehensive array of Innovative programs, resources and services."

The Foundation Program fully embraces the institution's mission and vision of equipping students with knowledge, skills and competencies that meet international standards while at the same time empowering students to shape the future of the UAE. It also attempts to align with the hybrid learning model which aspires to prepare students holistically by simultaneously endowing students academically yet preparing them for the workplace.

GARD teachers through the ASP collaborate closely with the Bachelor programs by encouraging the students to participate as peer tutors to help others with language level difficulties or by participating in events created by students for students. A popular event is the Program Choice where the diverse programs proudly exhibit their accomplishments. The Bachelor students guide the Foundation students through their exhibits with the purpose of showcasing the academic side of the program as well as the possibilities of employment available once they finish their studies. Thus, accomplishing another part of GARD's mission, namely, "enabling the successful transition of new students to their career programs by enhancing student engagement, integrating academic and co-curricular programs, and fostering both independent and lifelong learning."

\section{Conclusion}

In researching and reviewing the varied settings for this paper, we have learned that diverse models of dual language or bilingual education often have either cultural or historical foundations due to the influence of other countries (WWII, colonization) or other determining factors (discovery of petroleum). The researchers have also found that most countries carry out periodic revisions and evaluations of their models with the hope of improving them and offering a better service and yet, there is need for more research in the field. Another important aspect was the engagement and motivation of students and the population in participating in bilingual programs alongside teacher qualification and skillfulness. Other concerns include the variety in the way different countries face their linguistic policies regarding ages to start integrating the second language; the number of languages included in the programs, but mostly with a predominance of English; the number of versions of the CLIL model and even the names of the plans themselves: bilingual, dual language, multilingual or plurilingual.

With regards to our proposed combination of the 90/10 and 50/50 model, it has yet to yield conclusive results and will require further research after implementation. Finally, regardless of the model, the researchers propose that the conservation of the mother tongue and its culture while implementing the second and even third or fourth languages should be a priority in any model or country. 


\section{References}

Azzam, Z. (2015). In Search of Bilingualism in Dubai's Private K-12 Education Sector. In Working Papers Series. International and Global Issues for Research, 1, 1-36.

Baker, C., \& Wright, W. E. (2017). Foundations of bilingual education and bilingualism (6th ed.). Bristol: Multilingual Matters.

Benítez, M. (2018, August 22). El próximo curso sólo habrá diez centros bilingües más en Sevilla. ABC Sevilla. Retrieved from https://sevilla.abc.es/sevilla/sevi-proximo-curso-solo-habra-diez-centros-bilingues-massevilla-201808202337_noticia.html

Bialystok, E. (2006). Bilingualism in development: language, literacy \& cognition. Cambridge, Cambridge University Press.

Cabello, A. (2017, February 23). Planes bilingües en Europa. El Correo de Andalucía. Retrieved from $\mathrm{http}: / /$ elcorreoweb.es/andalucia/planes-bilingues-en-europa-XN2681257

Chomsky, N. (1965). Aspects of the Theory of Syntax. Cambridge, Massachusetts: The MIT Press. https://doi.org/10.21236/AD0616323

Collier, V. P., \& Thomas, W. P. (2004). The astounding effectiveness of dual language education for all. NABE Journal of Research and Practice, 2 (1), 1-20.

Council of Europe. (2018, May 29). Companion Volume with new descriptors. Retrieved from https://rm.coe.int/cefr-companion-volume-with-new-descriptors-2018/1680787989

Council of Europe. (2001). Common European Framework of Reference for languages: Learning, Teaching Assessment. Retrieved from https://rm.coe.int/16802fclbf

Consejería de Educación y Ciencia de la Junta de Andalucía. (2017, June 7). Instrucciones de Funcionamiento 2017-2018. Retrieved from http://www.juntadeandalucia.es/educacion/portals/abaco-portlet/content/ f575fa79-803d-4bd8-b248-b9a4ebbdc183

Council of Europe. (2019, May 23). Policy Portal. Retrieved from https://www.coe.int/en/web/language-polic

Council of Europe. (2019, May 23). Details of Treaty No.018 European Cultural Convention. Retrieved from https://www.coe.int/en/web/conventions/full-list/-/conventions/treaty/018

Council of Europe. (2019, May 29). The Language Policy Programme in brief. Retrieved from https://www.coe.int/en/web/platform-plurilingual-intercultural-language-education/the-platform-in-the-cont ext-of-the-language-policy-programme

Cummins, J. (2008). BICS and CALP: Empirical and Theoretical Status of the Distinction. In B. Street, \& N. H. Hornberger (Eds.) Encyclopedia of Language and Education (2nd Edition, Volume 2: Literacy, pp. 71-83). New York: Springer Science + Business Media LLC.

Deshays, E. (2003). Come favorire il bilinguismo dei bambini. Novara: Red Edizioni.

European Centre for Modern Languages of the Council of Europe. (2019, May 29). Retrieved from https://www.ecml.at/Aboutus/AboutUs-Overview/tabid/172/language/en-GB/Default.aspx

Education United Arab Emirates. (2019, March 15). Retrieved from https://www.export.gov/article?id=United-Arab-Emirates-Education

Erickson, E. (1958). Young man Luther: A study in psychoanalysis and history. New York: W.W. Norton Company.

European Commission. (2011). Commission staff working document: Language competences for employability, mobility and growth (pp. 1-45, Rep. No. SWD (2012) 372 final). Strasbourg: European Commission. Retrieved from https://eur-lex.europa.eu/legal-content/NL/TXT/?uri=CELEX:52012SC0372

Euro Stat Statistics Explained. Foreign language learning statistics. (2018). Retrieved from https://ec.europa.eu/eurostat/statistics-explained/index.php/Foreign_language_learning_statistics\#Primary_e ducation

Gallagher, K. (2011). Bilingual education in the UAE: Factors, variables and critical questions. Education, Business and Society: Contemporary Middle Eastern Issues, 4(1), 62-79. https://doi.org/10.1108/17537981111111274

Habbash, M., \& Troudi, S. (2015). The Discourse of Global English and its Representation in the Saudi Context: 
A Postmodernist Critical Perspective. In R. Raddawi (Ed.), Intercultural Communication with Arabs (pp. 57-75). Singapore: Springer. https://doi.org/10.1007/978-981-287-254-8_5

Harrison, K. D. (Writer). (2018, November 11). Endangered Languages. Live performance in Manama, Bahrain at the National Geographic Learning Bahrain Educational Forum 2018: Partnering for Success.

Hopkyns, S. (2014). The effects of global English on culture and identity in the UAE: a double-edged sword. Learning and Teaching in Higher Education: Gulf Perspectives, 11(2). https://doi.org/10.18538/lthe.v11.n2.197

Krashen, S. D. (1981a). Second Language Acquisition and Second Language Learning. Elsevier. Retrieved from https://www.sk.com.br/sk-krash-english.html

Lindholm-Leary, K. (2012). Success and Challenges. In Dual Language Education. Theory into Practice, 51(4), 256-262. https://doi.org/10.1080/00405841.2012.726053

Marsh, D. (2012). Content and Language Integrated Learning (CLIL). A Development Trajectory. Córdoba, Spain: Servicio de Publicaciones de la Universidad de Córdoba.

Raddawi, R., \& Meslem, D. (2015). Loss of Arabic in the UAE: Is Bilingual Education the Solution? International Journal of Bilingual \& Multilingual Teachers of English, 2(3), 85-94. https://doi.org/10.12785/ijbmte/030203

Ray, J. M. (2009). A Template Analysis of Teacher Agency at an Academically Successful Dual Language School. Journal of Advanced Academics, 21(1), 110-141. https://doi.org/10.1177/1932202X0902100106

SurveyLang (n.d.): The European Commission outlined a detailed strategic approach for the creation of a European Survey on Language Competences in 2005. Retrieved from http://www.surveylang.org/About-SurveyLang/About-the-survey.html

Thaiss, Christopher. (1986). Language Across the Curriculum in the Elementary Grades. Urbana, Ill: ERIC Clearinghouse on Reading and Communication Skills and the National Council of Teachers of English.

Titone, R. (1993). Bilinguismo precoce ed educazione bilingue. Rome: Armando Editore.

Varghese, M. M., \& Park, C. (2010). Going Global: Can Dual-Language Programs Save Bilingual Education? Journal of Latinos and Education, 9(1), 72-80. https://doi.org/10.1080/15348430903253092

Weaver, F. (2015, August 31). Finland makes multilingualism easy. Retrieved from https://finland.fi/life-society/finland-makes-multilingualism-easy/ 


\section{Appendix A}

\section{The researchers' proposed combined model}

Table 1. Combined Dual Language Framework: 90/10 \& 50/50 Model

\begin{tabular}{|c|c|c|c|c|c|c|}
\hline $\begin{array}{l}\text { Grades: } \\
\text { (5-7 years for } \\
\text { CALP-Cogni- } \\
\text { tive Academic } \\
\text { Language } \\
\text { Proficiency) }\end{array}$ & $\begin{array}{l}\text { K-2nd } \\
(90 / 10 \\
\text { Model) }\end{array}$ & $\begin{array}{l}3-5 \text { th } \\
(50 / 50 \\
\text { Model })\end{array}$ & $\begin{array}{l}\text { 6-8th } \\
\text { (50/50 Model) } \\
\text { "Academic } \\
\text { identity is tied } \\
\text { to language } \\
\text { spoken." } \\
\text { (Gonzalez, } \\
\text { 2001) }\end{array}$ & $\begin{array}{l}9 \text { th } \\
(50 / 50 \\
\text { Model })\end{array}$ & $\begin{array}{l}\text { 10th }-11 \text { th } \\
(90 / 10) \&(100)\end{array}$ & $\begin{array}{l}\text { 12th } \\
(100) \\
(50 / 50)\end{array}$ \\
\hline Rationale & $\begin{array}{l}\text { LAD- } \\
\text { (Language } \\
\text { Acquisition } \\
\text { Device)- } \\
\text { Noam } \\
\text { Chomsky } \\
\text { \& Stephen } \\
\text { Krashen } \\
\text { "Universal } \\
\text { Grammar" }\end{array}$ & $\begin{array}{l}\text { Code } \\
\text { Switching- } \\
\text { Testing } \\
\text { Grades- } \\
\text { Test in } \\
\text { both target } \\
\text { Languages } \\
\text { in order to } \\
\text { show } \\
\text { cognitive } \\
\text { progress } \\
\text { and } \\
\text { growth }\end{array}$ & $\begin{array}{l}\text { Code } \\
\text { Switching- } \\
\text { Testing } \\
\text { Grades-Test in } \\
\text { both target } \\
\text { Languages in } \\
\text { order to show } \\
\text { cognitive } \\
\text { progress and } \\
\text { growth } \\
\text { "Erikson's } 8 \\
\text { Stages of } \\
\text { Development" }\end{array}$ & $\begin{array}{l}\text { Code } \\
\text { Switching- } \\
\text { Testing } \\
\text { Grades- } \\
\text { Test in } \\
\text { both target } \\
\text { Languages } \\
\text { in order to } \\
\text { show } \\
\text { cognitive } \\
\text { progress } \\
\text { and } \\
\text { growth }\end{array}$ & $\begin{array}{l}\text { (90/10) 1st semester } \\
(100) \text { 2nd semester } \\
\text { Full Language } \\
\text { Immersion-which } \\
\text { leads to- } \\
\text { "Full Cognitive } \\
\text { Academic Language } \\
\text { Proficiency" } \\
\text { (CALP) }\end{array}$ & $\begin{array}{l}(100) \quad 1 \text { st } \\
\text { semester } \\
\text { Code } \\
\text { Switching- } \\
(50 / 50) \\
\text { 2nd } \\
\text { semester } \\
\text { Cognitive } \\
\text { Academic } \\
\text { Language } \\
\text { Proficiency" } \\
\text { (CALP) }\end{array}$ \\
\hline
\end{tabular}

Implementation Phase in one grade level a year

Process

\section{Copyrights}

Copyright for this article is retained by the author(s), with first publication rights granted to the journal.

This is an open-access article distributed under the terms and conditions of the Creative Commons Attribution license (http://creativecommons.org/licenses/by/4.0/). 